${ }^{1}$ Max Planck Institut für Meteorologie, Hamburg, Germany

${ }^{2}$ Lawrence Berkeley National Laboratory, Berkeley, CA, USA

${ }^{3}$ Agency for the Assessment and Application of Technology, Jakarta, Indonesia

\title{
Seasonal variability of Indonesian rainfall in ECHAM4 simulations and in the reanalyses: The role of ENSO
}

\author{
E. Aldrian ${ }^{1,3}$, L. Dümenil Gates ${ }^{2}$, and F. H. Widodo ${ }^{3}$ \\ With 12 Figures
}

Received August 9, 2005; revised January 30, 2006; accepted January 31, 2006

Published online May 26, 2006 (C) Springer-Verlag 2006

\begin{abstract}
Summary
A study of the skill of the ECHAM version 4 atmospheric general circulation model and two reanalyses in simulating Indonesian rainfall is presented with comparisons to 30 years of rain gauge data. The reanalyses are those performed by the European Centre for Medium-Range Weather Forecasts and of the National Centers for Environmental Prediction jointly with National Center for Atmospheric Research. This study investigates the skill of the reanalyses and ECHAM4 with regard to three climate regions of Indonesia, the annual and interannual variability of rainfall and its responses to El Niño-Southern Oscillation (ENSO) events. The study is conducted at two spectral resolutions, T42 and $\mathrm{T} 106$.

The skill of rainfall simulations in Indonesia depends on the region, month and season, and the distribution of land and sea. Higher simulation skills are confined to years with ENSO events. With the exception of the northwest region of Indonesia, the rainfall from June (Molucca) and July (south Indonesia) to November is influenced by ENSO, and is more sensitive to El Niño than La Niña events. Observations show that the Moluccan region is more sensitive to ENSO, receives a longer ENSO impact and receives the earliest ENSO impact in June, which continues through to December. It is found that the reanalyses and the climate model simulate seasonal variability better than monthly variability. The seasonal skill is highest in June/July/August, followed by September/October/November, December/January/ February and March/April/May. The correlations usually break down in April (for monthly analysis) or in the boreal spring (for seasonal analysis). This period seems to act as a
\end{abstract}

persistent barrier to Indonesian rainfall predictability and skill. In general, the performance of ECHAM4 is poor, but in ENSO sensitive regions and during ENSO events, it is comparable to the reanalyses.

\section{Introduction}

The Indonesian Maritime Continent is an interesting region for climate research. In terms of atmospheric dynamics, this region is influenced by both the Hadley and Walker Cells. The seasonal to interannual variabilities of Indonesian rainfall are characterized mainly by the monsoon (Ramage, 1971) and the El Niño-Southern Oscillation (ENSO; Philander, 1989; Ropelewski and Halpert, 1987, 1989; Halpert and Ropelewski, 1992; Hendon, 2003). Indonesia experiences two phases of monsoon every year, the wet phase from November to March, which coincides with the presence of the Inter-Tropical Convergence Zone (ITCZ) in this region (Asnani, 1993), and the dry phase from May to September, when the dry southeasterly wind blows from Australia. Ramage (1971) and Cheang (1987) identified April and October as the transitional months. Annual and interannual climate variability in Indonesia is somewhat unusual, as it is not 
homogenous over the whole region (Wyrtki, 1956) and the coherence of rainfall patterns varies with season (Haylock and McBride, 2001). ENSO contributes to the rainfall pattern in this area and its influence is interconnected with the monsoons (Lau and Nath, 2000). During El Niño (La Niña) events or warm (cold) phases, this region experiences lower (higher) rainfall than in other years (Gutman et al., 2000). Many discussions of Indonesian rainfall variability in relation to ENSO have used the Southern Oscillation index (SOI). For example Braak (1919), Berlage (1927), Schell (1947), Reesinck (1952) and later Nicholls (1981) reported a good correlation between rainfall variations in Indonesia and the SOI. Here, we will use another ENSO diagnostic, the NINO3 sea surface temperature (SST), which has been used by many ENSO forecasting groups, e.g. (Barnston et al., 1999).

Recent analyses extends to include atmospheric general circulation model (AGCM) simulations. Goddard et al. (2001) provided a comprehensive review of the seasonal and inter-annual skill of climate simulations over recent decades, including the performance of AGCMs in general. Barnett et al. (1997) conducted a predictability analysis of mid-latitude climate on ensembles of simulations with ECHAM4 (Roeckner et al., 1996a) and the NCEP atmospheric model and found that the models' skill was higher by about $50 \%$ during strong SST events in the tropical Pacific. Moron et al. (1998) examined the skill and reproducibility of seasonal rainfall in the tropics for the ECHAM4 model at resolution T30. They found that with regard to the June to September inter-annual variability over southeast Asia from Pakistan to Taiwan (including Indonesia), the skill of ECHAM4 is mainly confined to years of strong tropical Pacific SST variability. A GCM study by Neale and Slingo (2003) found that substantial errors in the simulation of the diurnal cycle in the maritime continent would lead to errors in seasonal mean climate.

There have been many studies on the quality of the simulated rainfall for the National Centers for Environmental Prediction and National Center for Atmospheric Research (NCEP-NCAR) reanalysis (Kalnay et al., 1996) and the ERA15 (Gibson et al., 1997) from the European Centre for Medium-Range Weather Forecasts (ECMWF). Janowiak et al. (1998) found good agreement with regard to large scale features and substantial differences in regional precipitation between the NCEP reanalysis and observations from the Global Precipitation Climatology Project (GPCP; WCRP 1990). Stendel and Arpe (1997) found that ERA15 precipitation fields were superior in the extra-tropics to other reanalyses when compared with GPCP data. Annamalai et al. (1999) found ERA15 to be better than other reanalyses in describing the Asian summer monsoon, while Newman et al. (2000) point to a substantial problem with the precipitation in the warm pool area near the Maritime Continent by all reanalyses.

This study is motivated by findings from two previous works, which analyzed the long term variability of Indonesian rainfall from rainfall station data (Aldrian and Susanto, 2003) and simulations of the Indonesian rainfall using a regional model (Aldrian et al., 2004). Both studies found persistent behavior of the climatic pattern within the data (the former) and within the regional model itself (the latter) during spring, which is eventually related to ENSO activity and is region dependent. Regional model simulations in Aldrian et al. (2004) were driven by boundary forcings from two reanalyses and ECHAM4 model as explained above. Whether the boundary forcings convey similar messages to these findings will be investigated in this study.

The purpose of this study is a statistical assessment of the performance or skill of two reanalyses and the Max-Planck-Institute's atmospheric model ECHAM4 in simulating the variability of Indonesian rainfall as documented by gauge observation, and the role of ENSO. The study will focus on monthly and seasonal means and interannual aspects of rainfall in dominant climatic regions. One of the problems in simulating Indonesian rainfall is the land-sea representation. Most of the study area is highly complex with oceans and chains of islands, which are difficult to represent even in a high-resolution models. Due to the high level of heterogeneity in the region, it has to be speculated that the typical horizontal resolution used in GCMs cannot adequately represent the complex interactions of mountains, air and sea. We have therefore included a higher resolution GCM simulation in the region and classified regions according to major climate controls using rain gauge data. 
The outline of this paper is as follows. Section 2 discusses data and the ECHAM4 model, Sect. 3 regional and annual climate cycle analyses, Sect. 4 inter-annual variability, and Sect. 5 seasonal and monthly variability. In Sect. 6 the relationship between rainfall variability and ENSO is investigated. Finally, Sect. 7 presents conclusions.

\section{Data and model}

The data used in this study are monthly rainfall data collected by the Indonesian Meteorological \& Geophysical Agency (BMG) at 526 stations across Indonesia, and monthly mean rainfall data from the WMO-NOAA Global Historical Climatology Network project (GHCN; Vose et al., 1992) from 1961 to 1993 which are similar to data used in Aldrian and Susanto (2003). The data have passed some quality control tests including homogeneity testing before they were incorporated into GHCN (Peterson et al., 1998). In our area of interest $\left(15^{\circ} \mathrm{S}-8^{\circ} \mathrm{N}\right.$ and $\left.95^{\circ} \mathrm{E}-145^{\circ} \mathrm{E}\right)$, there are 884 rain gauges. These data are gridded to match the other datasets at the T42 and T106 resolutions. The extension of the interpolation from the land gauge data into ocean areas should create no problem, since Aldrian et al. (2005) found good agreement between simulated rainfall over oceans in this region using a coupled ocean atmospheric model and rainfall data as are used here.

This study uses two reanalysis data sets. The first is ERA15 (Gibson et al., 1997), which is available at the horizontal resolutions of T42 and T106 (the original calculation) or equivalent to $2.8125^{\circ}$ and $1.125^{\circ}$ in the tropics, respectively, from 1979 until 1993. The second is the 40 year NCEP reanalysis (NCEP; Kalnay et al., 1996), for the time period 1961 to 1993 with a fixed spatial resolution of $\mathrm{T} 62$ (equivalent to $2.5^{\circ}$ in the tropics). For comparison with other T42 products, a regridding procedure was applied to convert the NCEP grid format from T62 into T42.

The ECHAM4 (Roeckner et al., 1996a) model is a spectral model with a triangular truncation at the wavenumbers 42 (T42) and 106 (T106). For the vertical representation a 19 level hybrid sigma-pressure coordinate system is used. The orography and land-sea mask are calculated from a high resolution $(1 \mathrm{~km})$ US Navy data set. Unfortunately, due to limited computer re-
Table 1. Resolutions and time span of data sets used

\begin{tabular}{lll}
\hline & Resolution & Time span \\
\hline $\begin{array}{l}\text { Rain gauge } \\
\text { data }\end{array}$ & T42/T106 & 19611993 \\
ERA15 & T42/T106 & 19791993 \\
NCEP & $\begin{array}{l}\text { T42 (regridded } \\
\text { from T62) }\end{array}$ & 19611993 \\
ECHAM4 & T42/T106 & T42: $19791993 ;$ \\
& & T106: 19791988
\end{tabular}

sources, the T106 output is available only for 10 years from 1979-1988, while the coarser resolution (T42) is available from 1979-1993 (see Table 1). The ECHAM4 model was driven by interannually varying SSTs from the Atmospheric Model Intercomparison Project 2 (Gates, 1992; Gates et al., 1999) at both resolutions.

In addition, SST data from the GISST2 (Global Ice and Sea Surface Temperature) dataset (Rayner et al., 1996) are used. This dataset is compiled from SST observations from 19031994 with a spatial resolution of $2.5^{\circ}$, and is used to determine the ENSO years. The relatively coarse resolution of this data set is not of main concern here, because only an area average for NINO3 $\left(5^{\circ} \mathrm{S}-5^{\circ} \mathrm{N}, 150^{\circ} \mathrm{W}-90^{\circ} \mathrm{W}\right)$ is taken into account. With the definition of an ENSO year by Roeckner et al. (1996b) SST anomalies are classified as an ENSO event if they are larger than $1^{\circ} \mathrm{K}$ in amplitude and persist for more than one year in the NINO3 region. As a result, the ENSO years from 1961-1993 are as follows:

El Niño year: 1965/1966, 1969/1970, 1972/ 1973, 1982/1983, 1987/1988, and 1991/1992 La Niña year: 1964/1965, 1970/1971, 1973/ 1974, 1975/1976, and 1988/1989

\section{Regional annual cycle analysis}

Due to high horizontal variability in this region (Haylock and McBride, 2001), there is a need to classify regions according to their annual rainfall cycles. The first regionalization attempt was made by Wyrtki (1956) when he divided the Indonesian waters into nine subregions. Here, we use the climate regionalization by Aldrian and Susanto (2003), who divided the Maritime Continent into three climate regions (Fig. 1), the southern Region A, the northwestern Region 


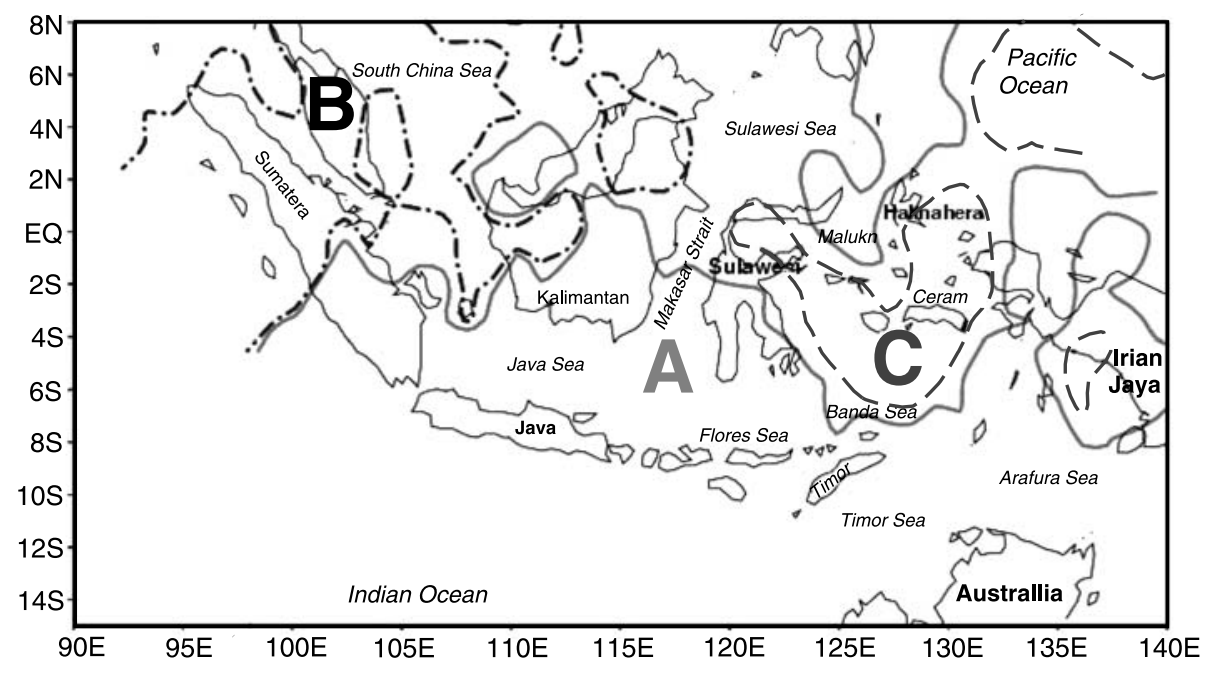

Fig. 1. Three climate regions from Aldrian and Susanto (2003), which divides Indonesia into region A (solid curve); the southern monsoonal region, region $\mathrm{B}$ (dashed-dotted curve); the semi-monsoonal region and region C (long dashed curve); the anti monsoonal region
B and the Moluccan Region C. Almost similar characters of the three regions were found by Wyrtki (1956) and Hamada et al. (2002), although they did not describe clear regions. Similar regions are applied in this study.

The annual cycle given by observed data at the T106 resolution in Region A is shown in Fig. 2. We observe a maximum in December/January/ February (DJF) and a minimum in July/August/ September (JAS). This illustrates two monsoon regimes: the wet northeast monsoon from November to March (NDJFM) and the dry southeast monsoon from May to September (MJJAS). With a strong monsoonal cycle and the southern location, we refer to this region as the southern monsoonal region. The annual cycle of Region B has two peaks, in October/November/December (OND) and March/April/May (MAM). The peaks in OND and in MAM represent the southward and northward movements of the ITCZ respectively. Davidson et al. (1984) and Davidson (1984) described in detail the ITCZ movement in this region in the boreal winter. We thus call Region B the northwest semi-monsoonal region. We also note in Fig. 2 that Region $\mathrm{C}$ is quite different from the others and has a peak in May/ June/July (MJJ), and we therefore refer to this region as the Molucca anti-monsoonal region.

Along with the annual cycle from observations, Fig. 2 shows the annual cycle of ERA15 and ECHAM4 at T106 resolution over the corresponding regions of Fig. 1. Patterns in Region A for ECHAM4 and ERA15 agree well with observations although the peaks of the wet season are less than observed. It is interesting to note that in Region A ERA15 and ECHAM4 show a very similar annual march. In Region B, ERA15 produces more rainfall than is observed throughout the year, which contrast with the lower rainfall simulated by ECHAM4. However, their correlations with regard to time with observations are above 0.80 , which means that the representation of the annual cycle is excellent. In Region C, the performances differ considerably. Here, the annual peak from ERA15 and ECHAM4 is found in MAM instead of in MJJ, and there is a strong overestimation of December rainfall. Some difference plots between the simulated rainfall from ERA15 (or ECHAM4) and observed rainfall (not shown) indicates that these peaks represent an earlier northward movement of the ITCZ.

At T42 resolution (Fig. 3) the reanalyses and model behave differently. In Region $\mathrm{A}$, the reanalyses agree well and follow the observed annual cycle and they are particularly good in JAS, but again underestimate the wet DJF. ECHAM4 has a peak in MAM instead of NDJ and extends the wet season far too long into May and June. In Region B, ECHAM4 considerably overestimates rainfall from June to October i.e. during the dry period. In this region ERA15 shows an almost perfect annual cycle. NCEP has a similar annual cycle but underestimates the peak in OND. In Region C, ECHAM4 and ERA15 again misplace the peak observed in June and July. The worst correlation in Region $\mathrm{C}$ is with NCEP, which is considerably different from the observations. In fact, NCEP's annual cycle is similar to that in Region A. Table 2 summarizes the reanalyses and model skills with regard to 
Region A

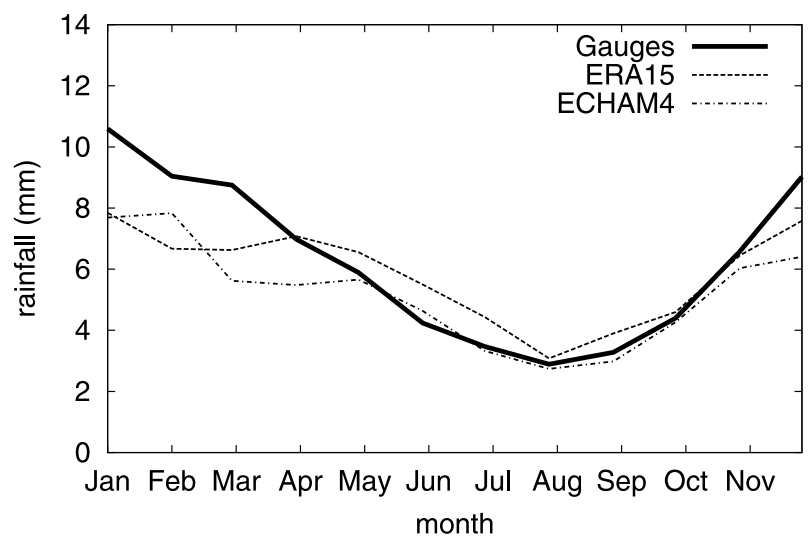

Region B

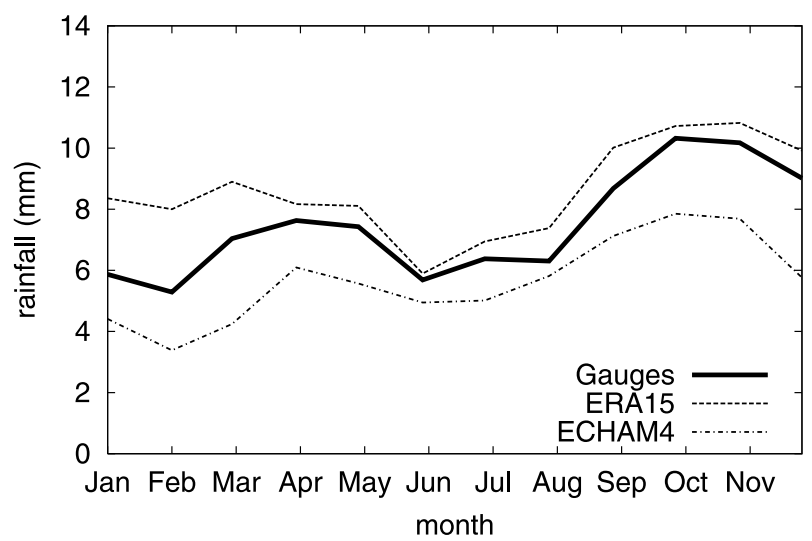

Region C

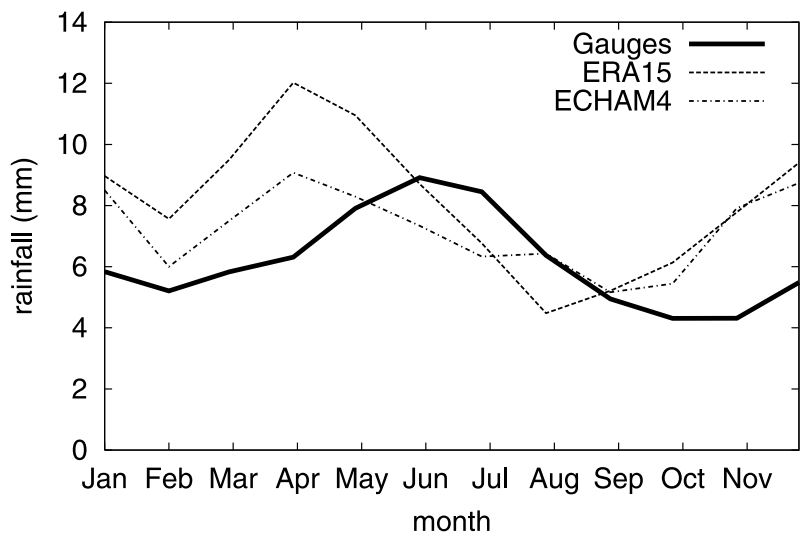

Fig. 2. The annual rainfall cycle ( $\mathrm{mm} /$ day) of each region at T106 resolution for observation with rain gauge (bold), ERA15 (thin dashed) and the ECHAM4 simulation (thin dot-dashed)

their annual cycles. The reanalyses simulate temporal patterns of Region A and B quite well, while ECHAM4 shows large errors in Region B. However, neither reanalyses nor model show good agreement in Region C.
Region A

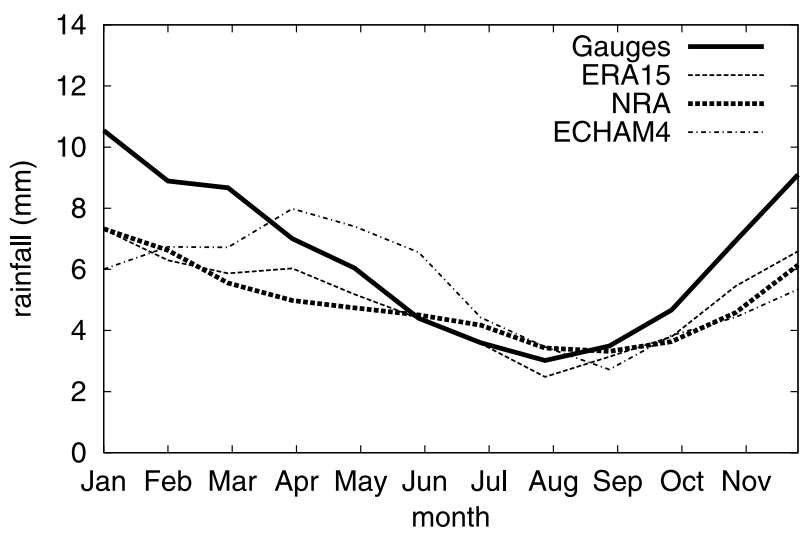

Region B
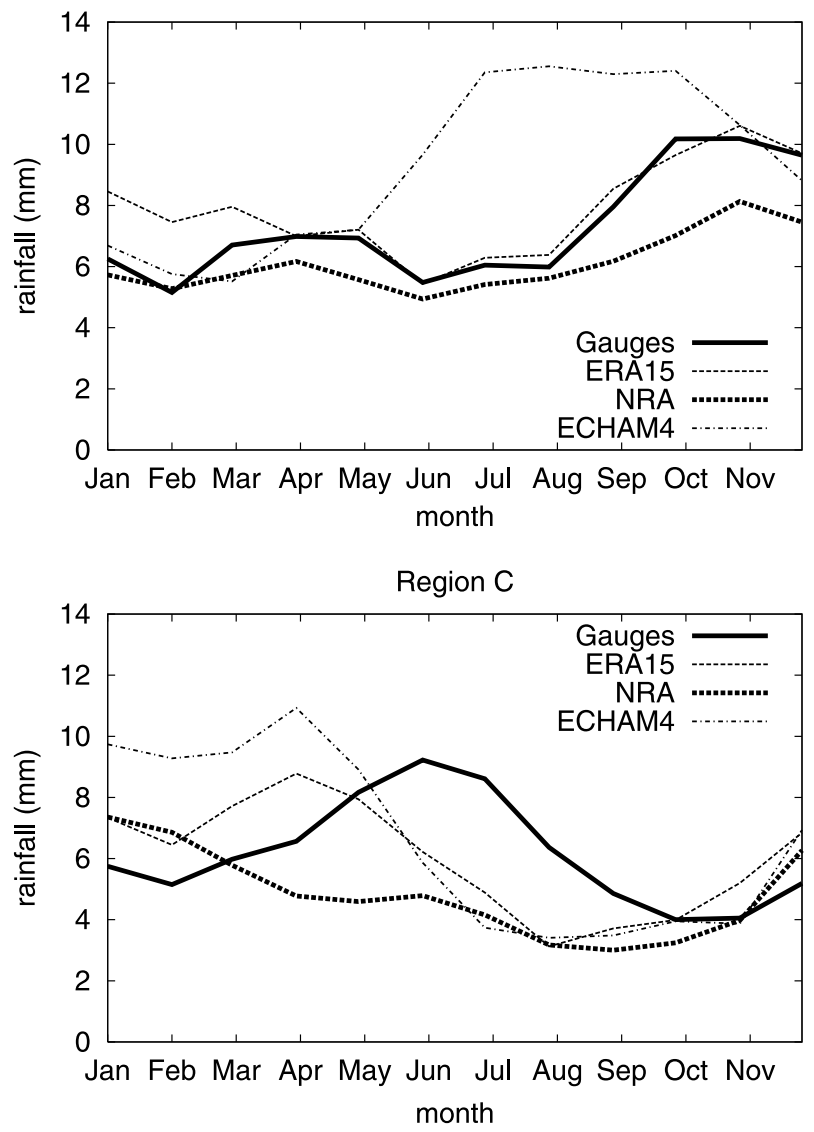

Fig. 3. As Fig. 2, but for the T42 resolution, and NCEP (bold dashed)

In summary, Figs. 2 and 3 show that NCEP has a poorly pronounced annual cycle with no clear peak. NCEP was produced at T62 and was truncated to T42, so should have the benefit of a higher resolution land-sea mask. Obviously, this information is not passed on to the atmosphere. In Region C, ERA15 has a clear peak at both resolutions, but it occurs too early in the year. 
Table 2. Correlations of ERA15, NCEP and ECHAM4 in three regions with the observed annual cycles

\begin{tabular}{|c|c|c|c|c|c|c|c|c|c|}
\hline & \multicolumn{3}{|l|}{ Region A } & \multicolumn{3}{|c|}{ Region B } & \multicolumn{3}{|c|}{ Region C } \\
\hline & $\begin{array}{l}\text { Obs - } \\
\text { ERA15 }\end{array}$ & $\begin{array}{l}\text { Obs - } \\
\text { NCEP }\end{array}$ & $\begin{array}{l}\text { Obs - } \\
\text { ECHAM }\end{array}$ & $\begin{array}{l}\text { Obs - } \\
\text { ERA15 }\end{array}$ & $\begin{array}{l}\text { Obs - } \\
\text { NCEP }\end{array}$ & $\begin{array}{l}\text { Obs - } \\
\text { ECHAM }\end{array}$ & $\begin{array}{l}\text { Obs - } \\
\text { ERA15 }\end{array}$ & $\begin{array}{l}\text { Obs - } \\
\text { NCEP }\end{array}$ & $\begin{array}{l}\text { Obs - } \\
\text { ECHAM }\end{array}$ \\
\hline $\mathrm{T} 42$ & $0.97^{* * *}$ & $0.94^{* * *}$ & $0.56^{* *}$ & $0.86^{* * *}$ & $0.97^{* * *}$ & $0.32^{*}$ & 0.27 & 0.01 & 0.13 \\
\hline T106 & $0.91^{* * *}$ & - & $0.93^{* * *}$ & $0.88^{* * *}$ & - & $0.88^{* * *}$ & 0.27 & - & 0.2 \\
\hline
\end{tabular}

$*, * *, * * *$ Correlations at 90,99 and $99.9 \%$ significance levels, respectively
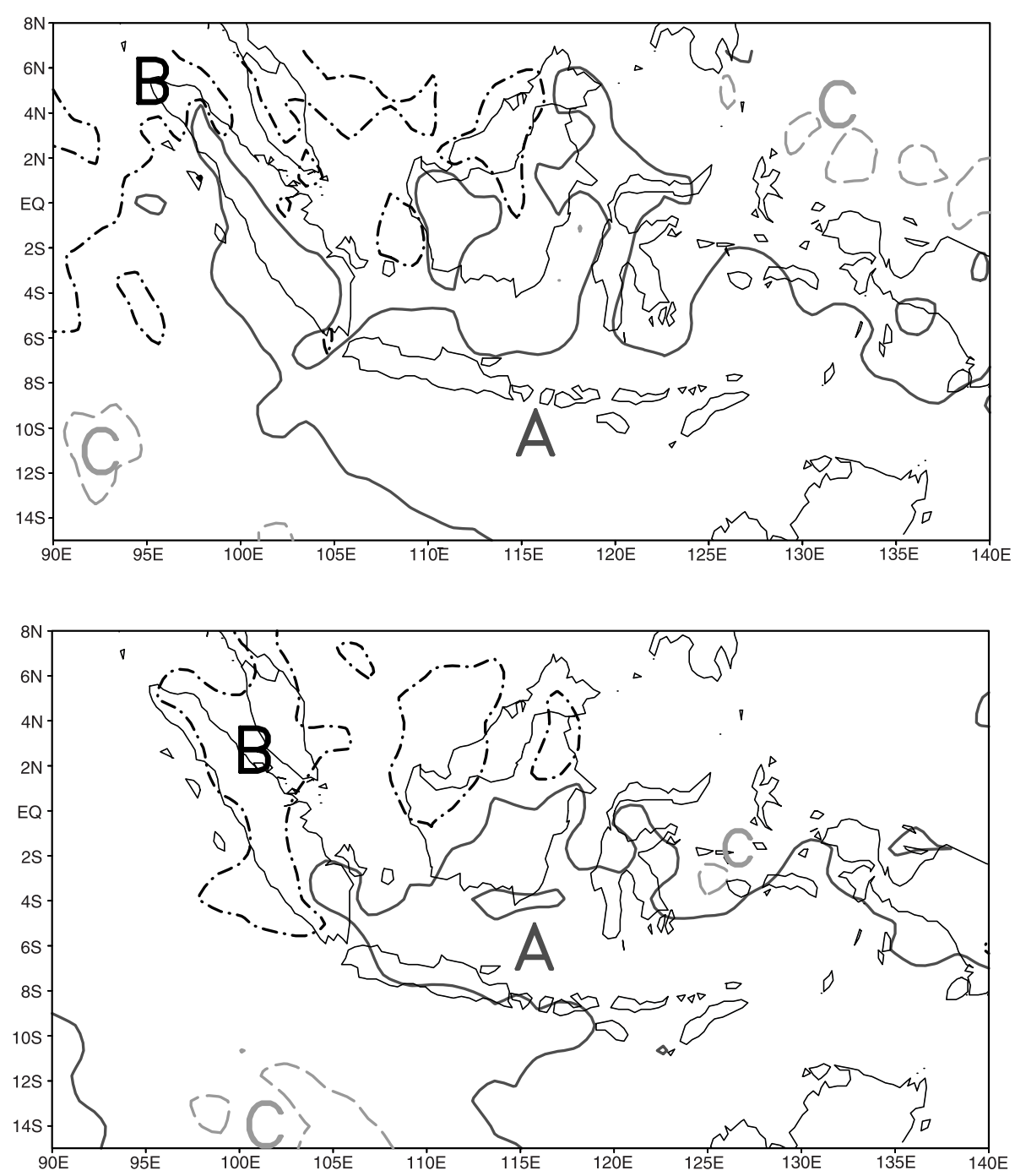

Fig. 4. As Fig. 1, the climate regions at the T106 resolution as simulated by ERA15 (above) and ECHAM4 (bottom) using annual rainfall patterns of gauges as shown in Fig. 2

ERA15 at a coarser resolution has a less pronounced annual cycle. The performance of ECHAM4 at higher resolution resembles that of ERA15, although is less pronounced, while ECHAM4, at the lower T42 resolution, disagrees with observations in all three regions.

This analysis can be used to explain the correlation values in Table 2 or the deviations of the annual cycles in Fig. 2. Figure 4 shows the regio- nalization that would result from ERA15 and ECHAM4 at T106 using the corresponding annual cycle procedure as in the observations (Fig. 2). In Fig. 4, for both ERA15 and ECHAM4, Regions $\mathrm{A}$ and $\mathrm{B}$, as expected, are located in southern and northwestern Indonesia, respectively. Meanwhile the climate of Region $\mathrm{C}$ is not in the correct location in ERA15. ECHAM4 represents Region C climate only for one grid 
cell in central Molucca plus some areas south of Indonesia. These results show that ERA15 and ECHAM4 cannot perform well with regard to Region $\mathrm{C}$ in the previous analysis. ECHAM4 gives a broader Region B while ERA15 gives a broader Region A, the latter indicating a wider dry area or area affected by the southeast monsoon and the former indicating a longer period of wet northeast monsoon. Another feature are the broader intermediate regions in both cases. The expected annual cycle of the intermediate region will be a flat one with two small peaks. Similar analysis at T42 resolution (not shown here) can be used to explain the values in Table 2 and the patterns in Fig. 3.

\section{Interannual variability}

The analysis of interannual variability in this study is based on monthly and seasonal (threemonthly) averages for the three climate regions. Figures 5 to 7 show interannual variations of sea- sonal means of rainfall for different seasons from observations (1961 to 1993), the two reanalyses, and ECHAM4 at T42. Values represent the interannual variation of rainfall after removing their averages and trends in units of standard deviation $(\sigma)$. In Fig. 5 for Region A there are good correlations between observations and NCEP in JJA and SON. Except for a weak El Niño of 1969, El Niño years coincide with rainfall below $-\sigma$ in JJA and SON. In general, the two reanalyses and the model simulation have the worst skill in MAM and the best in JJA. During extreme El Niño events such as in 1982, all show good skills from JJA and simulate this event quite well $(<-\sigma)$ as it extends to DJF, except ECHAM4 in DJF. In the case of the weak 1987 El Niño, all simulate the event only in JJA and SON. The impact of La Niña is not as clear as El Niño's and occurs only in SON. The La Niña events of 1964 , 1970, 1973 and 1975 have clear signals in SON. In general, the impact of El Niño on Region A is greater than the impact of La Niña. Chen and
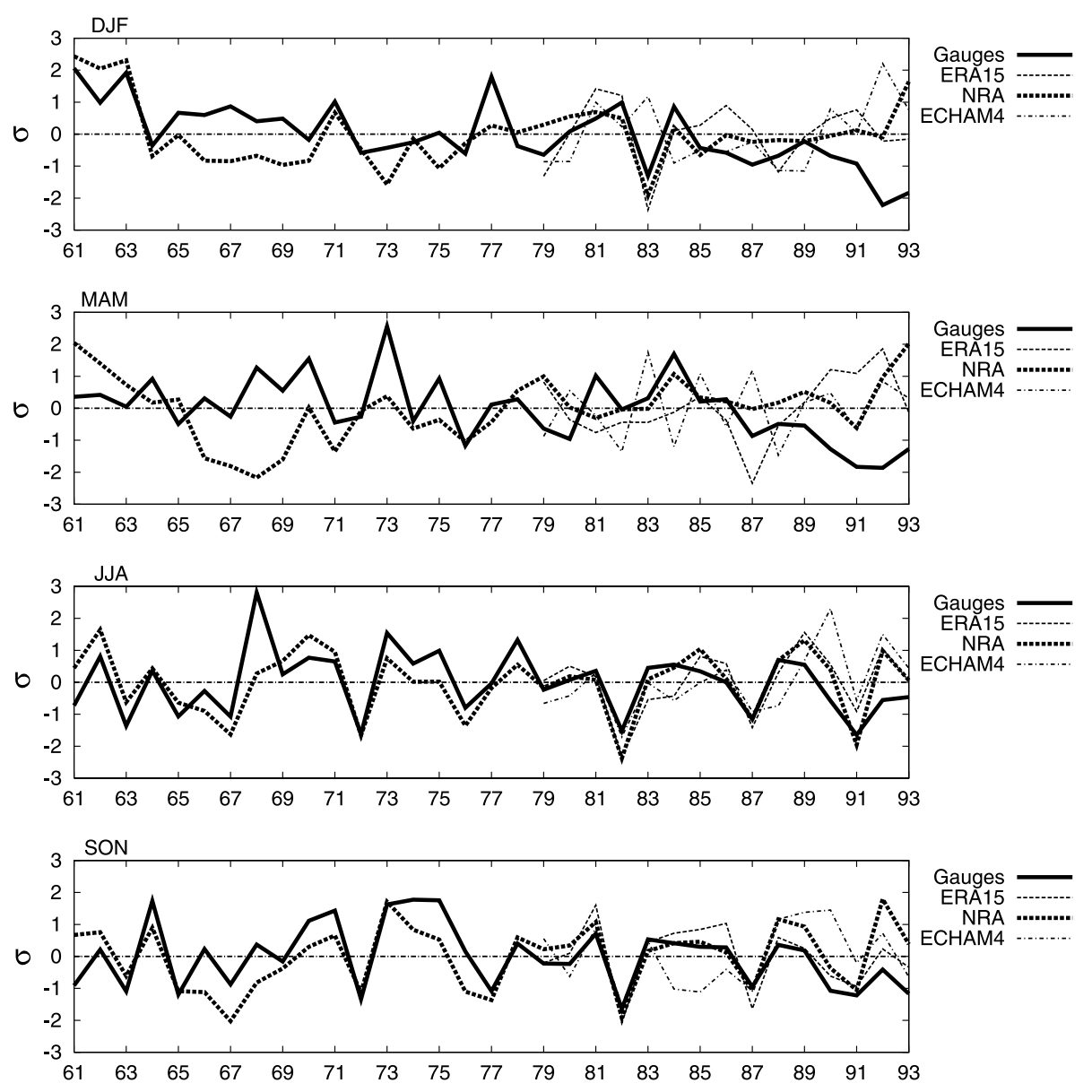

Fig. 5. The inter-annual variation indices of seasonal rainfall in region $\mathrm{A}$ at $\mathrm{T} 42$ resolution for observation (bold solid), ERA15 (thin dashed), NCEP (bold dashed) and ECHAM4 (thin dot-dashed). The ordinates are the variation of rainfall in units of standard deviation $(\sigma)$ 

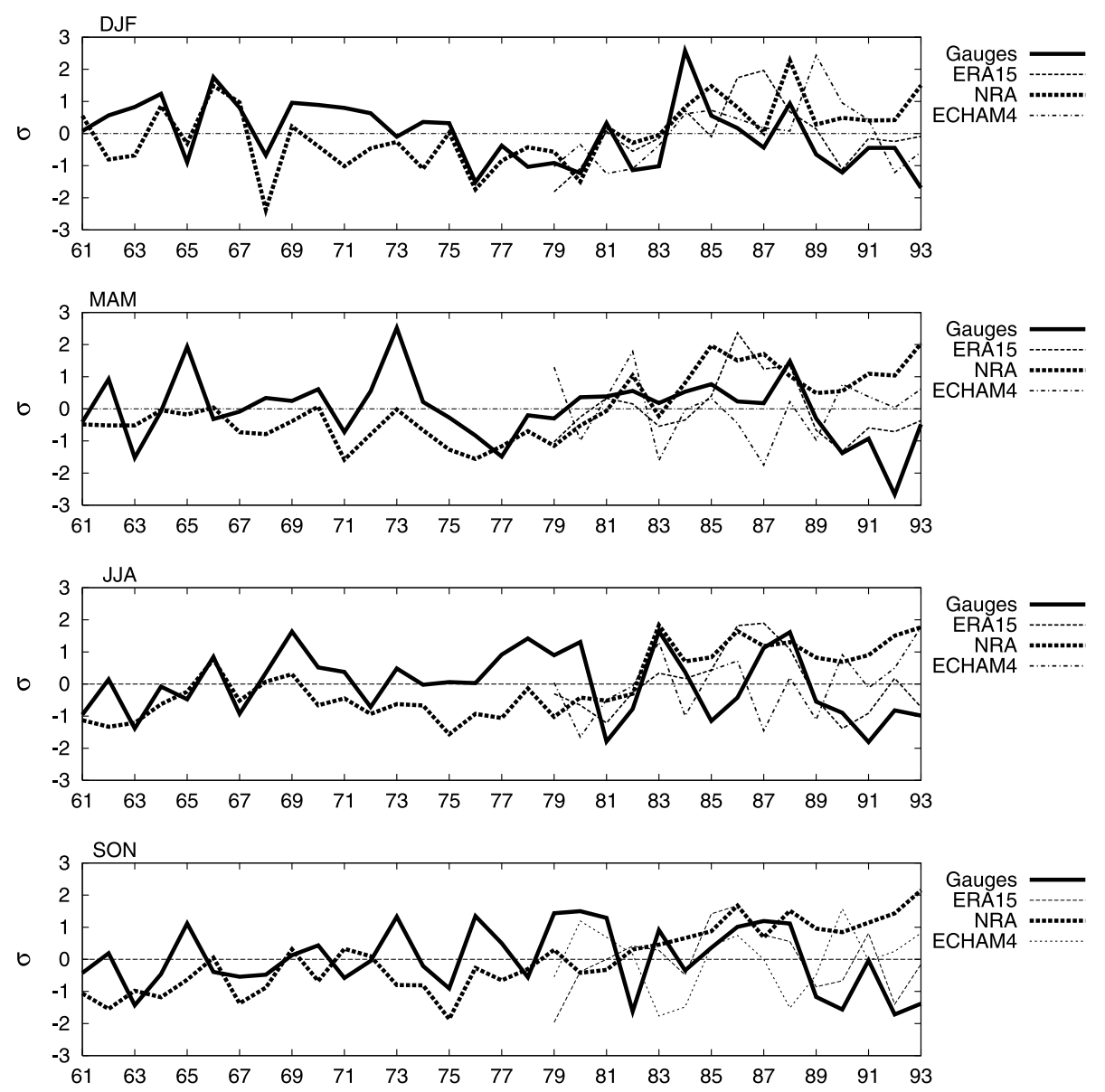

Fig. 6. As Fig. 5, but for region B

van den Dool (1997) indicated significantly higher predictability during El Niño phases than during La Niña.

Figure 6 shows similar results for Region B. Agreement between observed precipitation and reanalyses or ECHAM4 is low in all seasons. This region seems to show no El Niño effects on rainfall (Ropelewski and Halpert, 1987), unlike in Region A. Surprisingly, the peaks from observations in the spring (MAM) of El Niño year 1965 and La Niña years 1973 and 1988 are high. They may be connected to strong monsoon activities, as the ITCZ leaves Indonesia during this time of year.

Figure 7 illustrates the interannual variations for Region C. SON has the highest skill for reanalyses and ECHAM4. Like Region A, all have the worst skill in MAM. In SON, the variations during the El Niño events of 1982, 1987 and 1992 are well simulated by the reanalyses and the model. Like Region A, Region $\mathrm{C}$ receives strong El Niño impacts that last from JJA to DJF with smaller magnitudes. Smaller magni- tudes imply that Region A is more sensitive to El Niño than Region C. Since the El Niño impact or rainfall reduction occurs during the peak of the rainy season, the impact will be less devastating than for Region $\mathrm{A}$, which receives the impact during the dry season.

In the case of La Niña years there is no consistent feature among models and observations. In La Niña years 1964 and 1970, Region A has larger values in SON than in JJA. However, in JJA of the same year the index is higher in Region C. In La Niña year 1970, the variation index of Region $\mathrm{C}$ is higher in SON. All models show the La Niña of 1988 (JJA and SON) quite well. Reanalyses show the decreases of this La Niña activity in SON over Region A and C. In summary, reanalyses and ECHAM4 behave in accordance with observations only during extreme ENSO events. This agrees with the results of analyses of seasonal climate forecasts, which were found to be minimal in non-ENSO years (Barnston et al., 1994; Landman and Mason, 1999). An example of a non-ENSO year, when 

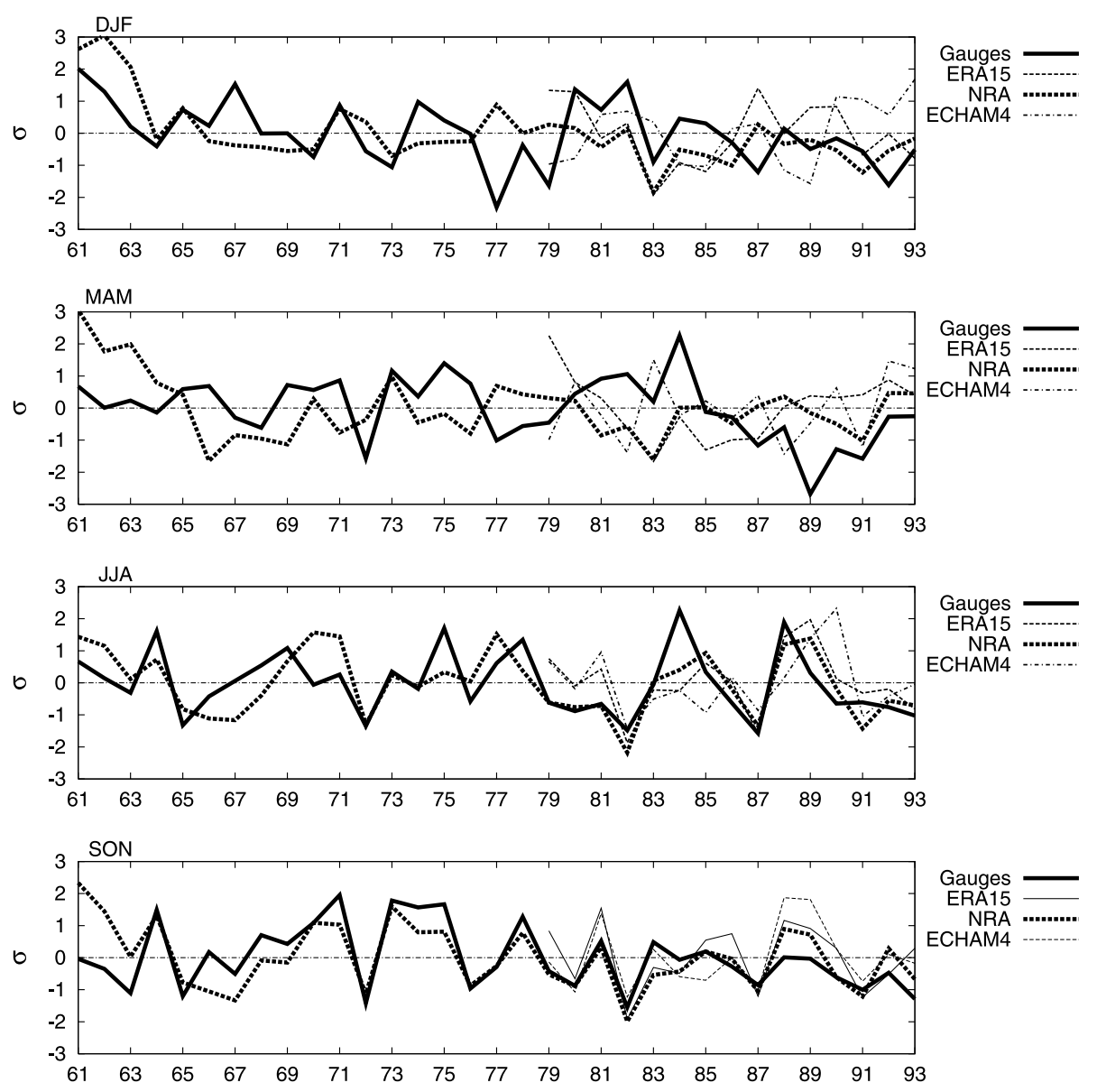

Fig. 7. As Fig. 5, but for region $\mathrm{C}$

the rainfall index is high in Regions A (JJA) and C (MAM and JJA) is 1984. The models do not simulate this well. The high rainfall index in this year is associated with a strong monsoon. Thus, models simulate variations due to ENSO events better than those due to monsoons.

\section{Seasonal and monthly variability}

In Fig. 8 the seasonal mean correlations between observations and reanalyses and the model simulations, respectively, are compared for resolutions of T42 and T106. With the exception of ECHAM4 at T106, which uses data from 1979-1988, correlations were calculated for data from 1979-1993. The measure of significant correlation is the $95 \%$ significance level.

Correlations show a distinct variation during the annual cycle. In Region A at T42, ECHAM4 has the same annual cycle variation as NCEP. Only ERA15 shows a good correlation in DJF. Except for ECHAM4 in JJA in Region C, the correlations are significant in Region $\mathrm{A}$ and $\mathrm{C}$ for JJA and SON. In Region C the NCEP reanalysis performs best. In Region $\mathrm{A}$ and $\mathrm{C}$, the least insignificant correlation is in MAM and the highly significant one in JJA. In Region B NCEP and ECHAM4 do not agree with the positive correlation of ERA15. There is a consistent breakdown of correlations in spring in Regions A and C. A weak signal, in this case a consistent breakdown of correlations, in MAM is known as the spring predictability barrier. The spring predictability barrier refers to a lower skill generally observed for predictions that extend through the boreal spring. Almost all discussions on the spring barrier are related to ENSO. Latif and Graham (1992) in a GCM experiment found that between April and June, the correlation coefficients between observed and predicted SST in the Pacific Ocean are much reduced in comparison to other periods, irrespective of when the prediction was commenced. Latif and Flügel (1991), Balmaseda et al. (1995), Davey et al. (1996), Moore and Kleeman (1996) described the ocean aspects of this barrier. Goswami and 

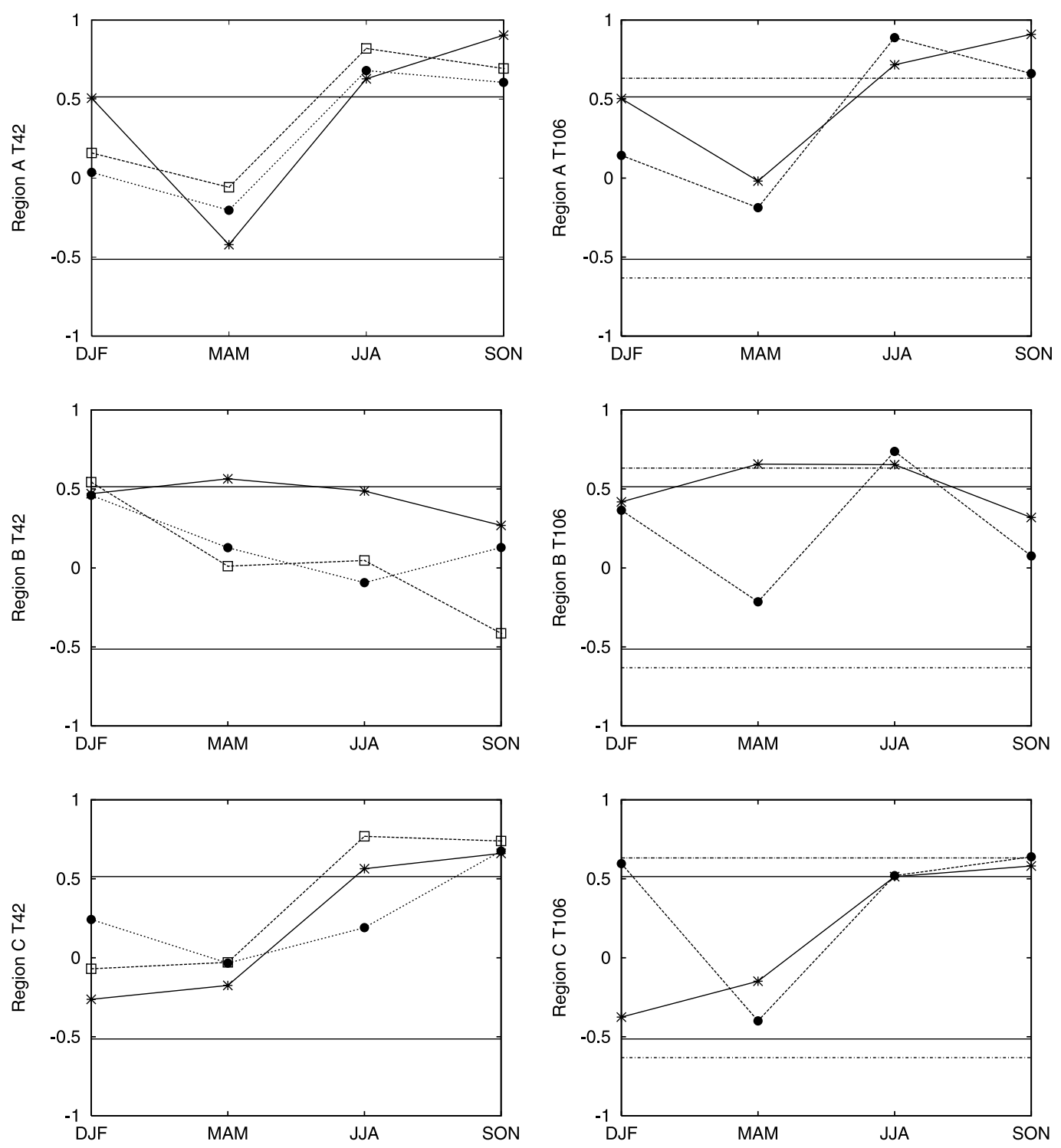

Fig. 8. The average seasonal correlation in region A (above), region B (middle) and region C (bottom) at T42 resolution (left) and at T106 resolution (right) between observation and ERA15 (*), NCEP ( $\square$ ) and ECHAM4 (•). Solid horizontal lines represent 95\% significance levels on two sides for all data except ECHAM4 at T106; dashed horizontal lines represent 95\% significance levels on two sides of ECHAM4 at T106

Shukla (1991), Blumenthal (1991), Flügel and Chang (1998), Latif et al. (1998) discussed the oceanic and atmospheric aspects of the barrier from coupled climate models. Weiss and Weiss (1999), Thompson and Battisti (2001) discussed the ENSO predictability with regard to the barrier. Furthermore, there are some studies that relate the barrier to the rainfall variability such as Webster and Yang (1992), Chen and van den Dool (1997), Yu et al. (1997). Unlike the other regions, there is no spring barrier signal in region B.

At the T106 resolution, the seasonal correlations of ERA15 and ECHAM4 in Region A are higher than those at T42. As at T42, the correlation breaks down in Regions $\mathrm{A}$ and $\mathrm{C}$ in the spring. Except for a low skill in DJF of ERA15 in Region $\mathrm{C}$, the skill in Region $\mathrm{A}$ and $\mathrm{C}$ in general is similar to that at T42. In Region B, ERA15 at T106 has a similar feature and a better skill than at T42. As in the case of the annual cycle, the performance of ECHAM4 in Region B is better for JJA at T106 than at T42. In Figs. 3 and 4, we saw that the annual cycle of ECHAM4 at T42 deviates significantly in JASO and the higher resolution improves the annual cycle. Furthermore, there is considerable improvement 

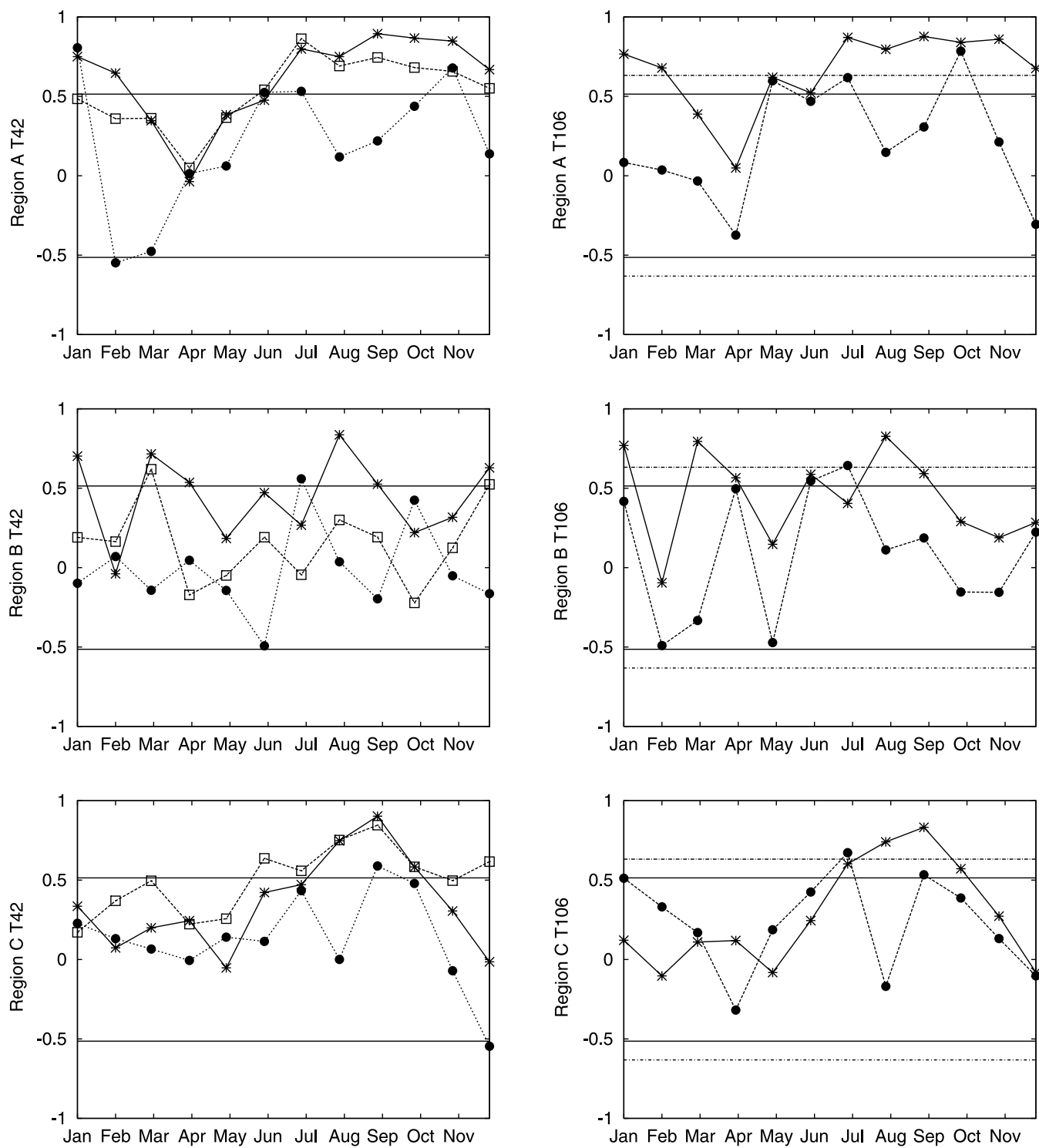

Fig. 9. As Fig. 8, but for the average monthly correlation

for ECHAM4 at the higher resolution in Region $\mathrm{A}$ and $\mathrm{C}$ in these seasons. In fact in JJA, ECHAM4 outperforms ERA15 in all regions. The inconsistent features in Region B at both resolutions suggest weak skill and low forcing by reanalyses and the ECHAM4 model. A similar signal is also observed in region B by Aldrian and Susanto (2003).

Figure 9 shows the monthly correlations of the T42 (left) and T106 (right) resolutions for the three regions. The variations from month to month are very high and do not retain the skill suggested before in seasonal mean analysis. In Region A at T42, the correlations of ECHAM4 are not in accordance with those of ERA15 and
NCEP, while the correlation of NCEP agrees well with that of ERA15. In Region B at T42, again the correlation of NCEP and ERA15 vary during the annual cycle in a similar way, but NCEP has much smaller values. ECHAM4, on the other hand does not agree with either of them. In Region C at T42, the annual cycle of the correlations of the three are alike with the exception of ECHAM4 in August. NCEP shows higher positive values while ERA15 and ECHAM4 agree at lower values across most of the year. In Region A at T106, ECHAM4 agrees well with the monthly correlation of ERA15 except in JA and $\mathrm{ON}$ and with lower values. In Region $\mathrm{B}$ at T106, ECHAM4 resembles ERA15, but with 
smaller values. Again in Region C, ECHAM4 is in phase with the variation of ERA15 except in August. The model shows yet again, as detected in the seasonal analysis of Regions A and C, the spring breakdown with the lowest correlations from February to April.

\section{Interannual variability related to ENSO}

From the above discussions, the impact of ENSO events is prominent in Regions A and C, that is, over most of Indonesia. Nicholls (1984) showed strong seasonal relations between SST in Indonesian waters and over the Pacific. Before that, Nicholls (1981) showed evidence of airsea interactions in Indonesia and that Indonesian rainfall is related to SST anomalies. Using the Southern Oscillation Index (SOI), an index based on the difference of mean sea level (MSL) pressure over Darwin and Tahiti, Ropelewski and Halpert (1989) showed that in an ensemble ENSO year annual variations of rainfall patterns
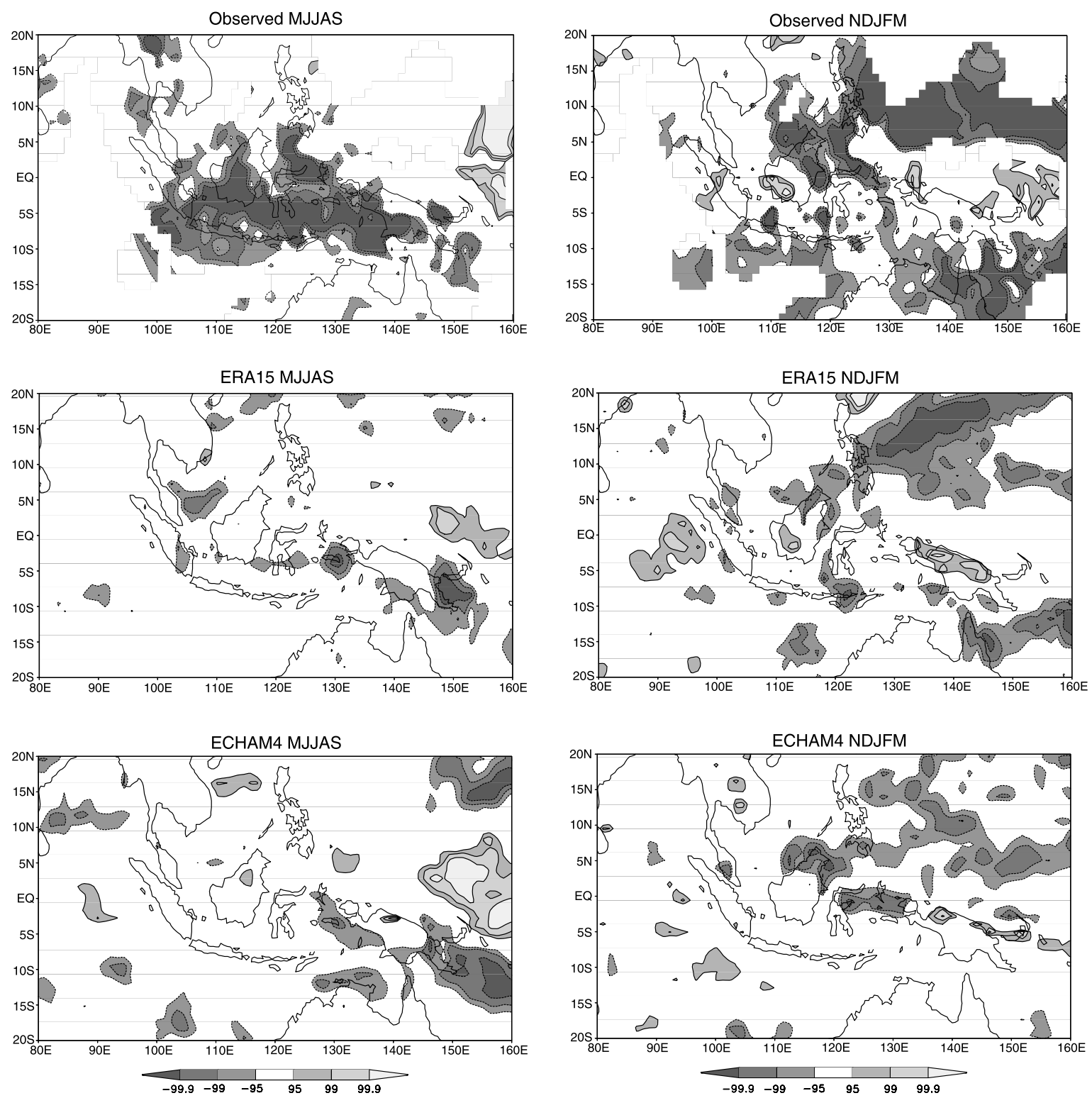

Fig. 10. Spatial patterns of rainfall - NINO3 SST correlations for observations (top), ERA15 (middle) and ECHAM4 (bottom) during MJJAS (left) and NDJFM (right) at T106 resolution. All are shown with their statistically significant correlation level, where the solid (dashed) lines represent positive (negative) correlation. The three level of gray scales on both sides represent 95, 99 and 99.9\% significance levels. For example, for observed data (1961-1993), these significant levels correspond to correlation values $|0.33|,|0.42|$ and $|0.52|$ respectively 
in Indonesia (except in northwest Indonesia) are $89 \%$ in coherence with SOI from 1885-1983, and that annual rainfall variations over Indonesia are associated with SST anomalies at 91\% coherence during July of ENSO event years until June of the following year. Ropelewski and Halpert (1987) calculated that in Indonesia (except the northwestern part) during the period of JuneNovember there is a coherence of interannual variation of rainfall with SOI of $82 \%$.

ENSO events characterize the seasonal and monthly skills of the reanalyses and the ECHAM4 simulation. During ENSO years, reanalyses, the model simulation and observations show good agreement, especially in JJA and SON. Our results confirm that ENSO is the main driving force of high skill, which is in agreement with Barnston et al. (1994) and Landman and Mason (1999). From Figs. 5 and 7, ECHAM4 variability agrees with observations strongly only during ENSO events. However, the high predictive skill of ENSO impact is lost when the correlations in Region A and $\mathrm{C}$ break down in spring.

\subsection{Spatial patterns of the rainfall sensitivity to NINO3 SST}

Figure 10 depicts the sensitivity of the Indonesian rainfall to NINO3 SST forcing during the dry monsoon (MJJAS) and the wet monsoon (NDJFM) (Ramage, 1971; Cheang, 1987). The sensitivity is indicated by the correlation between rainfall and NINO3 SST. This figure considers only correlation values with significance levels above 95,99 and $99.9 \%$.

The impact of ENSO as defined by the observations is more prominent during MJJAS with a significant coherent area of negative signals in most parts of Indonesia. Hendon (2003) found that Indonesian rainfall is highly coherent with remote SSTs during the dry half of the year (May-October). In NDJFM the observed rainfall data show significant negative responses to SST in south Indonesia, Molucca, northeast of Australia and a part of north Borneo. Some areas have good correlation values above $99 \%$ significance level in both seasons over 33 years (19611993). Region B does not have responses to NINO3 SST at all as shown by Ropelewski and Halpert (1987).
The ERA15 response in MJJAS is too weak and covers only a small area. In NDJFM, ERA15 shows good response over Kalimantan, north of the warm pool and south of New Guinea. ERA15 also gives a significant positive response in west Sumatera in NDJFM. ECHAM4 shows a too strong response in MJJAS east of $125^{\circ} \mathrm{E}$. In NDJFM, ECHAM4 gives a good response over Kalimantan, northern Molucca and north of the warm pool. For the remaining area, precipitation in ECHAM4 does not show a significant correlation to observations.

The exact period of ENSO impact on each region varies and needs further research on a seasonal or monthly basis. Chen and van den Dool (1997) and Haylock and McBride (2001) showed that ENSO cycle predictability has a large seasonal dependence.

\subsection{Seasonal and monthly variability related to ENSO}

Figure 11 illustrates the negative seasonal mean correlation between rainfall and NINO3 SST for the three regions. A high correlation is indicated for T42 only in JJA for Region C for the observations, and in JJA and SON for Regions A and $\mathrm{C}$ for ERA15. The two reanalyses follow the pattern for observations, especially in DJF, but are reduced to almost zero in MAM. In both these seasons, ECHAM4 gives erroneous positive correlations. The correlations between SST and precipitation for reanalyses and ECHAM4 follow closely the observations in Regions $\mathrm{A}$ and $\mathrm{C}$ with strong negative values in JJA and SON. For ECHAM4, there are significant (above 99\% correlation level) SST responses in SON $(-0.51)$ in Region A, MAM $(-0.52)$ in Region B and JJA (-0.47) and SON (-0.59) in Region C. In Region $\mathrm{B}$, correlations are insignificant indicating no ENSO effect.

At T106 resolution, the positive role of a higher resolution becomes very clear in the seasonal mean correlations of observations, ECHAM4 and ERA15. At this resolution, significant improvements of negative responses in JJA and SON, in agreement with observations, are seen for Regions A and C. ECHAM4 performance is improved and the breakdown of correlations in spring is even clearer with lower positive MAM values in Region C. Only in DJF and MAM for 

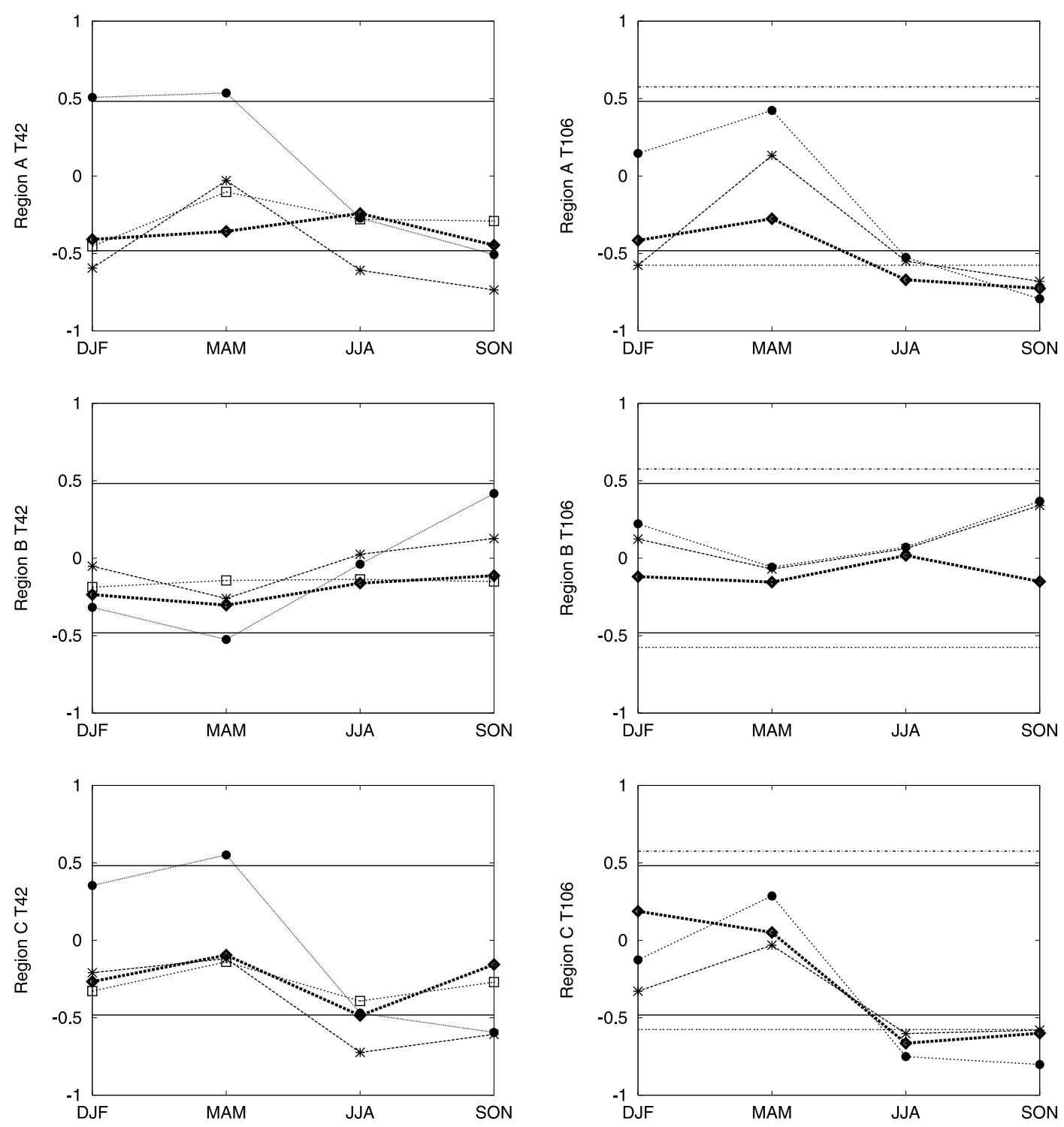

Fig. 11. The seasonal mean values of correlations between NINO3 SST and average rainfall in region A (above), region B (middle) and region C (bottom) at the T42 resolution (left) and the T106 resolution (right) of observed data ( $\bullet$ ), ERA15 ( $\left.{ }^{*}\right)$, NCEP $(\square)$ and ECHAM4 (•). Solid horizontal lines represent $95 \%$ significant levels on two sides of all data except ECHAM4 at T106, while dashed horizontal lines represent 95\% significant levels on two sides of ECHAM4 at T106

Region A are the deviations of ECHAM4 responses higher than the observations and reanalyses. No significant values in Region B again confirm that this region shows no ENSO influence at all. In Region B, ECHAM4 is very close to ERA15 and both have large errors compared

Table 3. The seasonal correlation of rainfall (from observations ECHAM4 and reanalyses) vs NINO3 SST

\begin{tabular}{|c|c|c|c|c|c|c|c|c|c|}
\hline & \multicolumn{3}{|c|}{ Region A } & \multicolumn{3}{|l|}{ Region B } & \multicolumn{3}{|c|}{ Region C } \\
\hline & $\begin{array}{l}\text { Obs - } \\
\text { ERA15 }\end{array}$ & $\begin{array}{l}\text { Obs - } \\
\text { NCEP }\end{array}$ & $\begin{array}{l}\text { Obs - } \\
\text { ECHAM }\end{array}$ & $\begin{array}{l}\text { Obs - } \\
\text { ERA15 }\end{array}$ & $\begin{array}{l}\text { Obs - } \\
\text { NCEP }\end{array}$ & $\begin{array}{l}\text { Obs - } \\
\text { ECHAM }\end{array}$ & $\begin{array}{l}\text { Obs - } \\
\text { ERA15 }\end{array}$ & $\begin{array}{l}\text { Obs - } \\
\text { NCEP }\end{array}$ & $\begin{array}{l}\text { Obs - } \\
\text { ECHAM }\end{array}$ \\
\hline $\mathrm{T} 42$ & 0.16 & 0.26 & -0.08 & $0.98^{* * *}$ & 0.19 & $0.97^{* * *}$ & $0.64^{*}$ & $0.90^{* * *}$ & 0.45 \\
\hline T106 & $0.81^{* *}$ & - & $0.99^{* * *}$ & -0.17 & - & -0.22 & $0.82^{* *}$ & - & $0.89^{* * *}$ \\
\hline
\end{tabular}

$*, * *, * * *$ Correlations at the 90,95 and $99 \%$ significance levels, respectively 

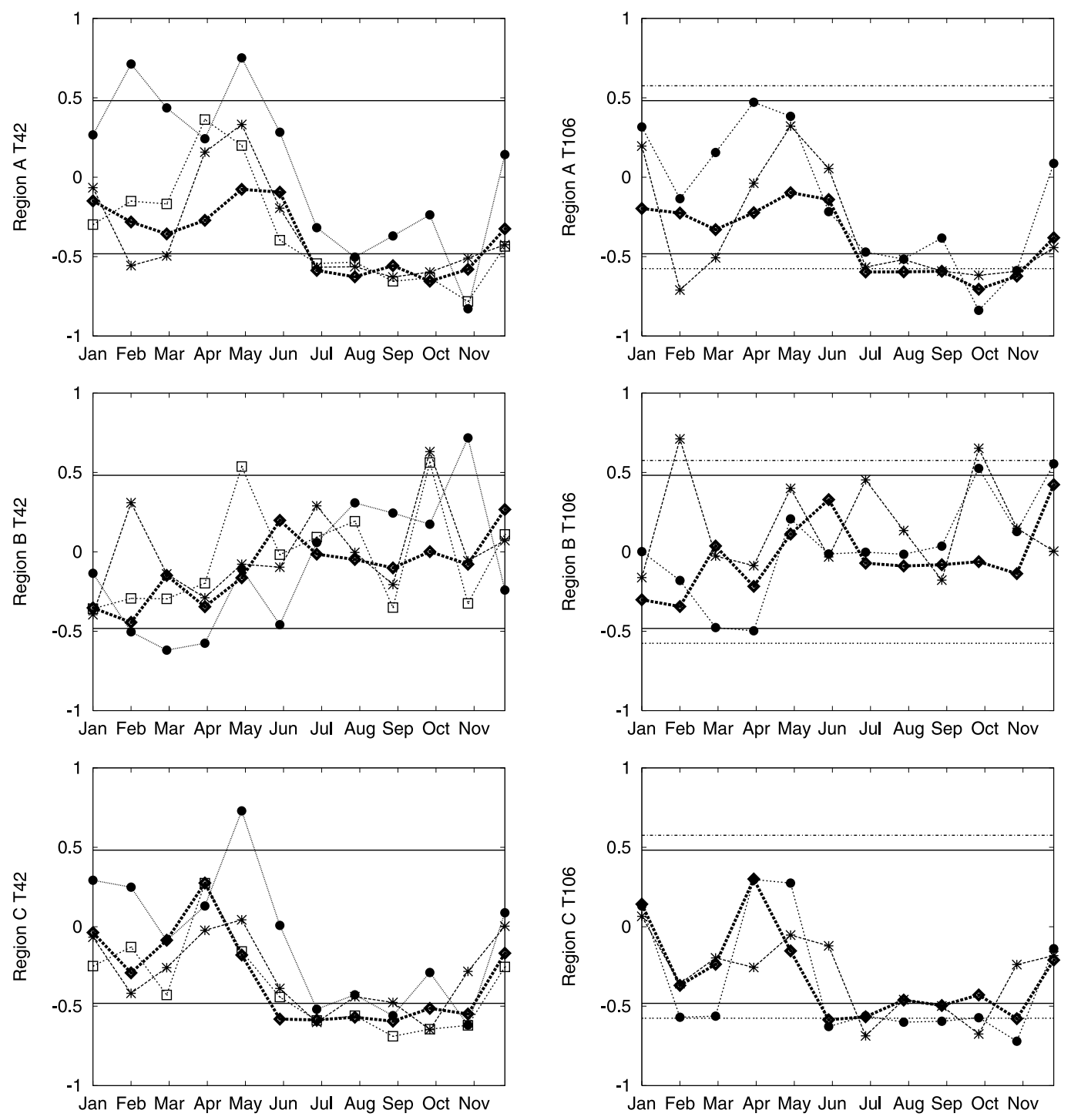

Fig. 12. As Fig. 11, but for the monthly mean correlations

to observations in SON and DJF. Increasing the resolution only improves the model simulation in MAM. A summary of seasonal rainfall response to SST variations at two different resolutions is given in Table 3.

The correlations for monthly means similar to Fig. 11 are shown in Fig. 12. At T42, the observations show more complicated structures and more significant correlations compared to the seasonal analysis in Fig. 11. Correlations between observations are significant from July to November in Region A and from June to November in Region C. In other words, the ENSO impact is significant in the dry period and the transition period to the wet period and ENSO has no impact on the peak of the wet northeast monsoon in DJF (Fig. 2). Hendon (2003) mentioned that Indonesian rainfall in the heart of the wet season tends to be uncorrelated with SST and spatially incoherent. A significant response of rainfall in Region C on NINO3 SST in June indicates that this region receives an ENSO impact earlier than Region A, and the rainfall in June foreshadows the ENSO event. However, there is no clear improvement at the higher resolution. In both resolutions, the reanalyses and the model follow the observed response between June and December in Regions $\mathrm{A}$ and $\mathrm{C}$ quite well. The observed data show that the correlations at T42 are higher than at T106 in Region C. In spring, the correla- 
Table 4. The monthly correlation of rainfall (from observations ECHAM4 and reanalyses) vs NINO3 SST

\begin{tabular}{|c|c|c|c|c|c|c|c|c|c|}
\hline & \multicolumn{3}{|l|}{ Region A } & \multicolumn{3}{|c|}{ Region B } & \multicolumn{3}{|c|}{ Region C } \\
\hline & $\begin{array}{l}\text { Obs - } \\
\text { ERA15 }\end{array}$ & $\begin{array}{l}\text { Obs - } \\
\text { NCEP }\end{array}$ & $\begin{array}{l}\text { Obs - } \\
\text { ECHAM }\end{array}$ & $\begin{array}{l}\text { Obs - } \\
\text { ERA15 }\end{array}$ & $\begin{array}{l}\text { Obs - } \\
\text { NCEP }\end{array}$ & $\begin{array}{l}\text { Obs - } \\
\text { ECHAM }\end{array}$ & $\begin{array}{l}\text { Obs - } \\
\text { ERA15 }\end{array}$ & $\begin{array}{l}\text { Obs - } \\
\text { NCEP }\end{array}$ & $\begin{array}{l}\text { Obs - } \\
\text { ECHAM }\end{array}$ \\
\hline $\mathrm{T} 42$ & $0.78^{* * *}$ & $0.69^{* * *}$ & $0.83^{* * *}$ & 0.24 & $0.42^{* *}$ & 0.22 & $0.78^{* * *}$ & $0.88^{* * *}$ & $0.66^{* *}$ \\
\hline T106 & $0.76^{* * *}$ & - & $0.84^{* * *}$ & -0.21 & - & $0.44^{* *}$ & $0.53^{* *}$ & - & $0.89^{* * *}$ \\
\hline
\end{tabular}

$*, * *, * * *$ Correlation at the 95,99 and $99.9 \%$ significance levels, respectively

tion breaks down in Region $\mathrm{A}$ and $\mathrm{C}$ as before. The correlation values of ECHAM4 for both resolutions exhibit erroneously high values in Regions $\mathrm{A}$ and $\mathrm{C}$ in the spring. As before, the performance of ECHAM4 improves considerably with increased higher resolution. NCEP and ECHAM4 in Region $\mathrm{C}$ have the best responses all year long, with correlation values of 0.88 with observations. In Region B, there is yet again no evidence of a significant ENSO impact.

\section{Concluding remarks}

We have examined the performance of two reanalyses and the ECHAM4 model with regard to rainfall over Indonesia at two different horizontal resolutions. In this study we used climate region classification with their own characteristic annual precipitation cycles; the southern monsoonal, the northwestern semi-monsoonal and the Moluccan anti-monsoonal. The analysis focused on regional, monthly and seasonal means as well as the annual cycle and interannual variability for the three climate regions previously defined. The correlation of rainfall to SST variations in the NINO3 region has also been investigated.

The simulated rainfall has a seasonal dependence and an ENSO cycle dependence. From the interannual analysis of Regions $\mathrm{A}$ and $\mathrm{C}$ (Figs. 5 and 7), El Niño (La Niña) years are indicated by rainfall index below $-\sigma$ (above $-\sigma$ ) in SON, except the very weak 1969 El Niño. Thus, the rainfall in SON in either region can be used as an ENSO index. The observations show that Region A is more sensitive to ENSO (Sect. 4), while Region $\mathrm{C}$ has the same length of ENSO impact as Region A and receives the earliest significant ENSO impact (Sect. 6). There is also no ENSO impact in the peak of the wet southeast monsoon. The reanalyses and ECHAM4 simulate variability during ENSO years better when co- herent signals appear especially during El Niño years. The study shows better seasonal than monthly model skills and shows the breakdown of the correlation in spring (MAM). The highest skill occurs in JJA, followed by SON, DJF and MAM. Haylock and McBride (2001) showed better predictability of Indonesian rainfall in SON than in DJF. The latter finding is in agreement with work carried out by Aldrian and Susanto (2003) and Aldrian et al. (2004). The first work found the strong (weak) response of the Indonesian rainfall, except in the northwestern region, to ENSO in SON (MAM), while the second work found similar signals of high (low) internal and external predictability in simulating the Indonesian rainfall in JJA (MAM) using a regional climate model. The first work represents variability of rainfall data and the second represents the skill of a regional model. The present work, represents the skill of a global climate model and two reanalyses over the region. The same reanalyses investigated here were used as the lateral boundary conditions for the work by Aldrian et al. (2004). From the three works discussed here, MAM seems to carry the persistent barrier for Indonesian rainfall predictability and skill. Moreover, the barrier in MAM has a strong relationship with ENSO events in the Pacific (Sect. 6).

Good skills in JJA suggest the potential to forecast ENSO, since the most severe environmental and socio-economic impact of ENSO on Indonesia occurs in SON (Kirono et al., 1999). Observed SSTs are used as lower boundaries for the reanalyses and slightly different AMIPII SSTs are used to run the ECHAM4 simulation. Nonetheless, the combination of meteorological data and SST yields only a very small correlation for reanalyses in spring (MAM). The observed SST applied to the model even yields an erroneous positive correlation. Trenberth and Caron (2000) showed a northward shift of a high corre- 
lation area between rainfall over Indonesia and SOI in MAM, whereas in other seasons the Maritime Continent is covered by strong correlations. Besides rainfall variability, signatures of the ENSO impact, the spring correlation breakdown and annual cycles are better represented by the higher resolution model.

Indonesia, with the exception of Region B, experiences consistent ENSO related rainfall anomalies. These results are in agreement with the results of Ropelewski and Halpert (1987, 1989), Halpert and Ropelewski (1992). The present study not only produces similar rainfallanomaly maps as shown by these authors, but also the seasonal march of impact received in each region. Southern Indonesia, or Region A, is the most El Niño sensitive region. Future work could include the extension of the analysis with ERA40 (Simmons and Gibson, 2000) and with the entire NCEP reanalyses time series.

\section{Acknowledgements}

This research was partially supported by the German Ministry of Research and Education (BMBF) Project INO-009-98 in collaboration with BPP Teknologi, Indonesia. The first author was granted a DAAD scholarship A/99/09410. We thank Prof. Hartmut Graß1 who reviewed the manuscript and supervised the study. Special thanks to Tien Sribimawati, her group and BMG Indonesia for providing rainfall data. Calculations have been performed at the Deutsches Klimarechenzentrum (DKRZ).

\section{References}

Aldrian E, Susanto RD (2003) Identification of three dominant rainfall regions within Indonesia and their relationship to sea surface temperature. Int J Climatol 23: 1435-1452

Aldrian E, Gates LD, Jacob D, Podzun R (2004) Long-term simulation of Indonesian rainfall with the MPI regional model. Clim Dyn 22: 795-814

Aldrian E, Sein D, Jacob D, Gates LD, Podzun R (2005) Modelling Indonesian rainfall with a coupled regional model. Clim Dyn 25: 1-17

Annamalai H, Slingo JM, Sperber KR, Hodges K (1999) The Mean evolution and variability of the Asian summer monsoon Comparison of ECMWF and NCEP-NCAR reanalyses. Mon Wea Rev 127: 1157-1186

Asnani GC (1993) Tropical meteorology, vol. 1. Asnani, $603 \mathrm{pp}$

Balmaseda MA, Davey MK, Anderson DLT (1995) Decadal and seasonal dependence of ENSO prediction skill. J Climate 8: 2705-2715
Barnett TP, Arpe K, Bengtsson L, Ji M, Kumar A (1997) Potential predictability and AMIP implications of mid latitude climate variability in two general circulation models. J Climate 10: 2321-2329

Barnston AG, van den Dool HM, Zebiak SE, Barnett TP, Ji M, Rodenhuis DR, Cane MA, Leetmaa A, Graham NE, Ropelewski CR, Kousky VE, O'Lenic EA, Livezey RE (1994) Long-lead seasonal forecasts - Where do we stand? Bull Amer Meteor Soc 75: 2097-2114

Barnston AG, Glantz MH, He Y (1999) Predictive skill of statistical and dynamical climate models in forecasts of SST during the 1997-98 El Niño episode and the 1998 La Niña onset. Bull Amer Meteor Soc 80: 217-244

Berlage HP (1927) East-monsoon forecasting in Java., Verhandelingen 20, Koninklijk Magnetisch en Meteorologisch Observatorium te Batavia, Magnetic Meteorology Observation. Batavia, Indonesia, 42 pp

Blumenthal MB (1991) Predictability of a coupled oceanatmosphere model. J Climate 4: 766-784

Braak C (1919) Atmospheric variations of short and long duration in the Malay Archipelago. Verhandelingen 5, Koninklijk Magnetisch en Meteorologisch Observatorium te Batavia, Magnetic Meteorology Observation. Batavia, Indonesia, $57 \mathrm{pp}$

Cheang BK (1987) Short- and long-range monsoon prediction in Southeast Asia. In: Fein JS, Stephens PL (eds) Monsoons. John Wiley and Sons, Wiley Interscience Publication, 579-606 pp

Chen WY, van den Dool HM (1997) Atmospheric predictability of seasonal, annual and decadal climate means and the role of the ENSO cycle: a model study. J Climate 10: 1236-1254

Davey MK, Anderson DLT, Lawrence S (1996) A simulation of variability in ENSO forecast skill. J Climate 9: 240-246

Davidson NE (1984) Short-term fluctuations in the Australian monsoon during winter Monex. Mon Wea Rev 112: 1697-1708

Davidson NE, McBride JL, McAvaney BJ (1984) Divergent circulations during the onset of the 1978-79 Australian monsoon. Mon Wea Rev 112: 1684-1696

Flügel M, Chang P (1998) Does the predictability of ENSO depend on the seasonal cycle? J Atmos Sci 55: 3230-3243

Gates WL (1992) AMIP: The Atmospheric Model Intercomparison Project. Bull Amer Meteor Soc 73: 1962-1970

Gates WL, Boyle JS, Covey C, Dease CG, Doutriaux CM, Drach RS, Fiorino M, Gleckler PJ, Hnilo JJ, Marlais SM, Phillips TJ, Potter GL, Santer BD, Sperber KR, Taylor KE, Williams DN (1999) An overview of the results of the Atmospheric Model Intercomparison Project (AMIP I). Bull Amer Meteor Soc 80: 29-56

Gibson JK, Kallberg P, Uppala S, Hernandez A, Nomura A, Serrano E (1997) The ECMWF Re-Analysis (ERA) 1. ERA Description. ECMWF Reanalysis Project Report Series 1, ECMWF, [Available from the European centre for Medium-range weather forecasts, reading, UK], $71 \mathrm{pp}$ Goddard L, Mason SJ, Zebiak SE, Ropelowski CF, Basher R, Cane MA (2001) Current approaches to seasonal to 
interannual climate predictions. Int J Climatol 21: $1111-1152$

Goswami B, Shukla J (1991) Predictability of a coupledatmosphere model. J Climate 4: 3-22

Gutman G, Csiszar I, Romanov P (2000) Using NOAA/ AVHRR products to monitor El Niño impacts: focus on Indonesia in 1997-98. Bull Amer Meteor Soc 81: 1189-1205

Halpert MS, Ropelewski CF (1992) Temperature patterns associated with the Southern oscillation. J Climate 5: 577-593

HamadaJI, Yamanaka MD, MatsumotoJ,FukaoS, WinarsoPA, Sribimawati T (2002) Spatial and temporal variations of the rainy season over Indonesia and their link to ENSO. J Meteor Soc Japan 80: 285-310

Haylock M, McBride JL (2001) Spatial coherence and predictability of Indonesian wet season rainfall. J Climate 14: $3882-3887$

Hendon HH (2003) Indonesian rainfall variability: Impacts of ENSO and local air-sea interaction. J Climate 16: $1775-1790$

Janowiak J, Gruber A, Kondragunta CR, Livezey RE, Huffman GJ (1998) A comparison of the NCEP NCAR reanalysis rainfall and the GPCP rain gauge-satellite combined dataset with observational error considerations. J Climate 11: 2960-2979

Kalnay E, Kanamitsu M, Kistler R, Collins W, Deaven D, Gandin L, Iredell M, Saha S, White G, Woollen J, Zhu Y, Chelliah M, Ebisuza W, Higgins W, Janowiak J, Mo KC, Ropelewski C, Wang J, Leetmaa A, Reynolds R, Jenne R, Joseph D (1996) The NCEP/NCAR 40-year reanalysis project. Bull Amer Meteor Soc 77: 437-471

Kirono DGC, Tapper NJ, McBride JL (1999) Documenting Indonesian rainfall in the 1997/1998 El Niño event. Phys Geography 20: 422-435

Landman W, Mason SJ (1999) Operational prediction of South African rainfall using canonical correlation analysis. Int J Climatol 19: 1073-1090

Latif M, Flügel M (1991) An investigation of shot-range climate predictability in the tropical pacific. J Geophys Res 96: 2661-2673

Latif M, Graham NE (1992) How much predictive skill is contained in the thermal structure of an OGCM? J Phys Oceanogr 22: 951-962

Latif M, Anderson DLT, Barnett TP, Cane MA, Kleeman R, Leetma A, O'Brien J, Rosati A, Schneider E (1998) A review of the predictability and prediction of ENSO. J Geophys Res 103: 14,375-14,393

Lau NG, Nath MJ (2000) Impact of ENSO on the variability of the Asian-Australian monsoons as simulated in GCM experiments. J Climate 13: 4287-4308

Moore AM, Kleeman R (1996) The dynamics of error growth and predictability in a coupled model of ENSO. Quart J Roy Meteor Soc 122: 1405-1446

Moron V, Navarra A, Ward MN, Roeckner E (1998) Skill and reproducibility of seasonal rainfall patterns in the tropics in ECHAM-4 GCM simulations with prescribed SST. Clim Dyn 14: 83-100

Neale R, Slingo J (2003) The maritime continent and its role in the global climate: a GCM study. J Clim 16: 834-848
Newman M, Sardeshmukh PD, Bergman JW (2000) An assessment of the NCEP, NASA, and ECMWF reanalyses over the tropical west Pacific Warm Pool. Bull Amer Meteor Soc 81: 41-48

Nicholls N (1981) Air-sea interaction and the possibility of long-range weather prediction in the Indonesian archipelago. Mon Wea Rev 109: 2345-2443

Nicholls N (1984) The Southern oscillation and Indonesia sea surface temperature. Mon Wea Rev 112: 424-432

Peterson TC, Vose R, Schmoyer R, Razuvaev V (1998) Global historical climatology network (GHCN) quality control of monthly temperature data. Int J Climatol 18: 1169-1179

Philander SGH (1989) El Niño, La Niña, and the Southern oscillation. International geophysical series, vol. 46. Academic Press, 289 pp

Ramage C (1971) Monsoon meteorology. International geophysics series, vol. 15. Academic Press, 296 pp

Rayner NA, Horton EB, Parker DE, Folland CK, Hackett RB (1996) Version 2.2 of the global sea-ice and sea surface temperature data set, 1903-1994. Tech Note CRTN74, Climate Research, 35 pp

Reesinck JJM (1952) Some remarks on monsoon forecasting for Java. Verhandelingen 44, Kementrian Perhubungan Lembaga Meteorologi dan Geofisika, Jakarta, Indonesia, $22 \mathrm{pp}$

Roeckner E, Arpe K, Bengston L, Christoph M, Claussen M, Dumenil L, Esch M, Giorgetta M, Schlese U, Schulzweida U (1996a) The atmospheric general circulation model ECHAM-4: Model description and simulation of present-day climate. MPI Report 218, [Available from Max Planck-Institut für Meteorologie, Bundesstr. 55, D-20146, Hamburg, Germany], 90 pp

Roeckner E, Oberhuber JM, Bacher A, Christoph M, Kirchner I (1996b) ENSO variability and atmospheric response in a global coupled atmosphere-ocean GCM. Clim Dyn 12: 737-754

Ropelewski CF, Halpert MS (1989) Rainfall patterns associated with the high index phase of the Southern oscillation. J Climate 2: 268-284

Ropelewski CF, Halpert MS (1987) Global and regional scale rainfall patterns associated with the El Niño Southern oscillation (ENSO). Mon Wea Rev 115: 1606-1626

Schell II (1947) Dynamic persistence and its applications to long-range forecasting. vol. 8, Harvard Meteorological studies, blue hill observatory, Milton, MA, $80 \mathrm{pp}$

Simmons AJ, Gibson JK (2000) The ERA-40 Project Plan. ERA-40 Project Report Series 1, ECMWF, [Available from the European Centre for Medium-range Weather Forecasts, Reading, UK], 62 pp

Stendel M, Arpe K (1997) Evaluation of the hydrological cycle in reanalyses and observations. MPI Report 228, [Available from Max-Planck-Institut für Meteorologie, Bundesstrasse 55, 20146 Hamburg, Germany], $52 \mathrm{pp}$

Thompson CJ, Battisti DS (2001) A linear stochastic dynamical model of ENSO. Part II: Analysis. J Climate 14: 445-466 
Trenberth K, Caron JM (2000) The Southern oscillation revisited: sea level pressure, surface temperature, and precipitation. J Climate 13: 4358-4365

Vose RS, Schmoyer RL, Steurer PM, Peterson TC, Heim R, Karl TR, Eischeid JK (1992) The global historical climatology network: Long-term monthly temperature, precipitation, sea level pressure, and station pressure data. ORNL/CDIAC-53 NDP-041, 325 pp

WCRP (1990) Global rainfall climatology project: Implementation and data management plan. Tech Rep WMO/ TD-No. 367, World Climate Research Programme, WMO, Geneva, Switzerland, $47 \mathrm{pp}$

Webster PJ, Yang S (1992) Monsoon and ENSO: selectively interactive systems. Quart J Roy Meteor Soc 118: 877-925

Weiss JP, Weiss JB (1999) Quantifying persistence in ENSO. J Atmos Sci 56: 2737-2760

Wyrtki K (1956) The Rainfall over the Indonesian waters. Verhandelingen 49, Kementrian Perhubungan
Lembaga Meteorologi dan Geofisika, Jakarta, Indonesia, $24 \mathrm{pp}$

Yu ZP, Chu PS, Schroeder T (1997) Predictive skills of seasonal to annual rainfall variations in the US affiliated Pacific Islands: canonical correlation analysis and multivariate principal component regression approaches. J Clim 10: 2586-2599

Authors' addresses: Edvin Aldrian* (e-mail: edvin@ webmail.bppt.go.id), Max Planck Institut für Meteorologie, Bundesstraße 53, 20146 Hamburg, Germany; * Present affiliation: Agency for the Assessment and Application of Technology, UPTHB-BPPT, J1 MH Thamrin 8, Jakarta 10340, Indonesia; Lydia Dümenil Gates, Lawrence Berkeley National Laboratory, 1 Cyclotron Road, Berkeley, CA 94720, USA; F. Heru Widodo, Agency for the Assessment and Application of Technology, UPTHB-BPPT, J1 MH Thamrin 8, Jakarta 10340, Indonesia. 